\title{
Short-Term Photochemical and Biological Unreactivity of Macrophyte-Derived Dissolved Organic Matter in a Subtropical Shallow Lake
}

\author{
Ng Haig They, ${ }^{1}$ David Motta Marques, ${ }^{2}$ Rafael Siqueira Souza, ${ }^{2}$ \\ and Lúcia Ribeiro Rodrigues ${ }^{2}$ \\ ${ }^{1}$ Programa de Pós-Graduação em Ecologia, Instituto de Pesquisas Hidráulicas, Universidade Federal do Rio Grande do Sul, \\ 91501970 Porto Alegre, RS, Brazil \\ ${ }^{2}$ Instituto de Pesquisas Hidráulicas, Universidade Federal do Rio Grande do Sul, 91501970 Porto Alegre, RS, Brazil
}

Correspondence should be addressed to Ng Haig They; haig.they@gmail.com

Received 7 May 2013; Revised 5 July 2013; Accepted 7 July 2013

Academic Editor: Wen-Cheng Liu

Copyright (c) $2013 \mathrm{Ng}$ Haig They et al. This is an open access article distributed under the Creative Commons Attribution License, which permits unrestricted use, distribution, and reproduction in any medium, provided the original work is properly cited.

\begin{abstract}
Macrophytes have been associated with low bacterial metabolism in the littoral zones of lake Mangueira, but an explanation for this pattern is largely unknown. In this study, macrophyte-derived DOM was incubated in situ for the measurement of the effect of grazers, bacteria, and light on its degradation in three experiments. The water was separated in bulk, bacterial, and control $\left(+\mathrm{HgCl}_{2}\right)$ fractions and exposed to or hidden from sunlight for $120 \mathrm{~h}$. Unchange in bacterial variables in the bulk fraction suggested a combined control of radiation and grazing on bacteria. Light treatment increased bacterial density but not biomass and biovolume, while bacterial density decreased in the dark. Significant fading of water color in the bacterial fraction only occurred after light exposure, indicating a complementary pathway of light and bacteria. DOC and the Abs $250: 365$ ratio did not change with incubation, indicating no net change of DOC pool and reactivity. Due to continuous carbon loading from macrophytes and low UV irradiance, the very low rates of DOM degradation provide the mechanistic explanation for the observed impacts of macrophytes in lake's carbon metabolism in littoral zones.
\end{abstract}

\section{Introduction}

Macrophytes are important sources of carbon to the littoral zones of lakes, and these plants directly and indirectly (via support of epiphytes) contribute higher amounts of dissolved organic carbon (DOC) than do algal sources [1]. They are the main sustainers of bacterial production in some systems (e.g., [2]), but knowledge of their impact on the entire lake metabolism is still relatively sparse $[1,2]$.

Loading of macrophyte-derived carbon in littoral zones can create within-lake patchiness in the quantity and quality of organic carbon, thus causing differences in the composition of bacterial assemblages [3]. Patchy utilization of heterogeneous DOC by compositionally or adaptively different bacterial communities could affect the entire lake metabolism, because bacterial secondary production and respiration can be affected by the consumption of either high or low-molecular-weight compounds [4].

DOC derived from macrophytes is composed mostly of aromatic and aliphatic polymer-like compounds of high molecular weight [5] and hence presumably refractory and hence highly unreactive (i.e., with low capacity to undergo chemical reaction, specially oxidation) to bacterial consumption. This requires bacterial assemblages that inhabit humic lakes to use a different, more energy-expensive mechanism to exploit these compounds $[1,6]$. Moreover, this type of DOC is qualitatively deficient, with low nitrogen and phosphorus contents [7].

Once they enter the water, high-molecular-weight compounds can follow two degradation paths: they can be transformed into lower-weight compounds by microbial decomposition [3] or by photodegradation, a process that enhances 
bacterial growth because it releases low-molecular-weight compounds, making them directly available to bacteria [812]. These two routes, bacterial and photo-degradation, can also be complementary; that is, bacteria and light act in concert decomposing different fractions of the DOC pool (autochthonous, low-molecular-weight DOC mainly by bacteria and allochthonous, high-molecular-weight DOC mainly by light) [13]. Additionally, bacterivores (flagellates and ciliates) can enhance decomposition rates [14], because of enhanced bacterial production on protist excretions [15].

Evidence is accumulating that bacterial metabolism can be lower in the presence of macrophytes at some instances. Rooney and Kalff [16] surveyed nine lakes with different percentages of macrophyte coverage and found a significant decrease in the bacterial respiration rate with increasing macrophyte coverage. In southern Brazil, a study in shallow coastal lakes found that bacterial metabolism and biovolume were frequently lower in littoral than pelagic zones and associated this with the influence of macrophytes [17]. Therefore, the environmental metabolic pathways of the organic matter that originated from macrophytes are still not understood in these ecosystems.

Previous studies [17] have pointed that the bacterial degradation of macrophyte-derived carbon is lower in the littoral zone, but a mechanistic explanation is still lacking. We hypothesize that since macrophytes contribute with high loadings of refractory material [5], the photo-degradation may play a major role in breaking down DOC in littoral zones. In the present study, we designed three independent experiments carried out simultaneously to test the role of bacteria, bacteria under grazing pressure, and light in the degradation of DOC derived from macrophytes entering the littoral zone of the lake Mangueira, a large subtropical shallow lake.

\section{Materials and Methods}

2.1. Study Site. Lake Mangueira ( 80800 ha, state of Rio Grande do Sul, Southern Brazil) is a large, shallow coastal subtropical lake (Figure 1). Extensive belts of wetlands are located north and south of the lake. The experiments were carried out in situ with water from a channel that drains a large wetland belt into the southernmost part of the lake (coordinates: $-33^{\circ} 31^{\prime} 45.48^{\prime \prime},-53^{\circ} 7^{\prime} 56.64^{\prime \prime}$ ). This channel has high coverage of submersed macrophytes, and the water entering the lake is highly colored compared to the adjacent waters in the pelagic zone. Hence, we assume that most of the DOC found in this water is mainly originated by macrophytes. This lake has been investigated for phytoplankton, zooplankton, benthos, and ecological modelling [18, 19] within the Brazilian Long-Term Ecological Research Program (PELD-Taim), and part of the lake lies within a conservation unit (ESEC-Taim). Only one study concerning heterotrophic bacteria in Lake Mangueira has been published so far [17].

The National Institute of Meteorology (INMET) station located at Santa Vitória do Palmar $\left(-33^{\circ} 31^{\prime} 00^{\prime \prime},-53^{\circ} 21^{\prime} 00\right.$, Altitude: $24.01 \mathrm{~m}$ ) provided meteorological data such as mean air temperature (AT). No noticeable precipitation was recorded during the experiment. Global Radiation (GR) (the sum of the radiation that come directly from the sun plus diffused radiation) was estimated by satellite [20] supported by the Brazilian National Institute of Space Research (CPTEC-INPE). Total radiation (accumulated global radiation) during the experiment was calculated from the daily mean flux radiation times the hours of sunshine (provided by INMET). Accumulated UV radiation was estimated by multiplying the total radiation by $2.3 \times 10^{-3}$, which is the proportion of UV radiation in total radiation. The daily UV-index ( 1 unit $=25 \mathrm{~mW} \mathrm{~m}^{-2}$ ) during the experiment was provided by INPE (National Institute of Space Research: <http://www.inpe.br/>).

2.2. Channel Water Characterization. All the following variables were measured in triplicates in the channel water to characterize the experimental conditions: alkalinity was measured through Gran titration method and the $\mathrm{pH}$ with a potentiometer (Tecnopon MPA 210p, Piracicaba, SP, Brazil) [21]. Total solids (TS) were measured gravimetrically through water evaporation in porcelain dishes [22]. Total nitrogen (TN) and total phosphorus (TP) were measured by colorimetry [23]. Dissolved organic carbon (DOC) was determined by a TOC Analyzer (Shimadzu VCPH, Columbia, MD, USA) as the fraction that passed through a $450^{\circ} \mathrm{C}$ precombusted glass fiber filter (Macherey-Nagel GF6, $0.6 \mu \mathrm{m}$ mean particle retention size). Absorbance at $430 \mathrm{~nm}$ was measured as an estimate of water color and the proportion of low- to highmolecular-weight substances as the ratio Abs250:365 [8, 24]. To determine the total density of ciliates, $50 \mathrm{~mL}$ of the sample was fixed with lugol (9/1, vol/vol) and samples were stored in the dark and cold. Total samples were counted in sedimentation chambers under an inverted microscope and reported as individuals $\times 10^{4} \mathrm{~m}^{-3}$ [21]. Bacterial production, respiration, and $B G E$ were measured the same way as for the experiment (see below).

Alkalinity, pH, Abs430, and Abs250:365 were measured immediately in the field laboratory. Samples for TS, TN, and $\mathrm{TP}$ were immediately frozen in $1 \mathrm{~L}$ polyethylene bottles. DOC samples were collected in $30 \mathrm{~mL}$ precombusted $\left(450^{\circ} \mathrm{C}\right.$ for $\left.1 \mathrm{~h}\right)$ amber glass bottles and acidified with $\mathrm{H}_{3} \mathrm{PO}_{4}{ }^{-3}$.

2.3. Experimental Procedure. Surface water was collected in the channel with the help of a plastic bucket and brought to the field laboratory. We set up three independent and simultaneous experiments: we separated the water into bulk, bacterial, and control fractions and measured variables in triplicates in the initial condition and exposed (light) or not (dark) to sunlight, totaling 27 incubation bags. The bulk fraction, with no filtration, was used to evaluate the effect of grazing; the bacterial fraction was obtained after filtration on MN 640d Macherey-Nagel paper filters (mean retention size of 2.0 to $4.0 \mu \mathrm{m}$ ) in order to exclude most bacterivores. This unusually permissive retention size was the best found to isolate bacteria and retain all metazoans, ciliates, and most flagellates in many previous pilots with different filters (including less permissive ones) ([17], and this study). The control was obtained after the same filtration as 

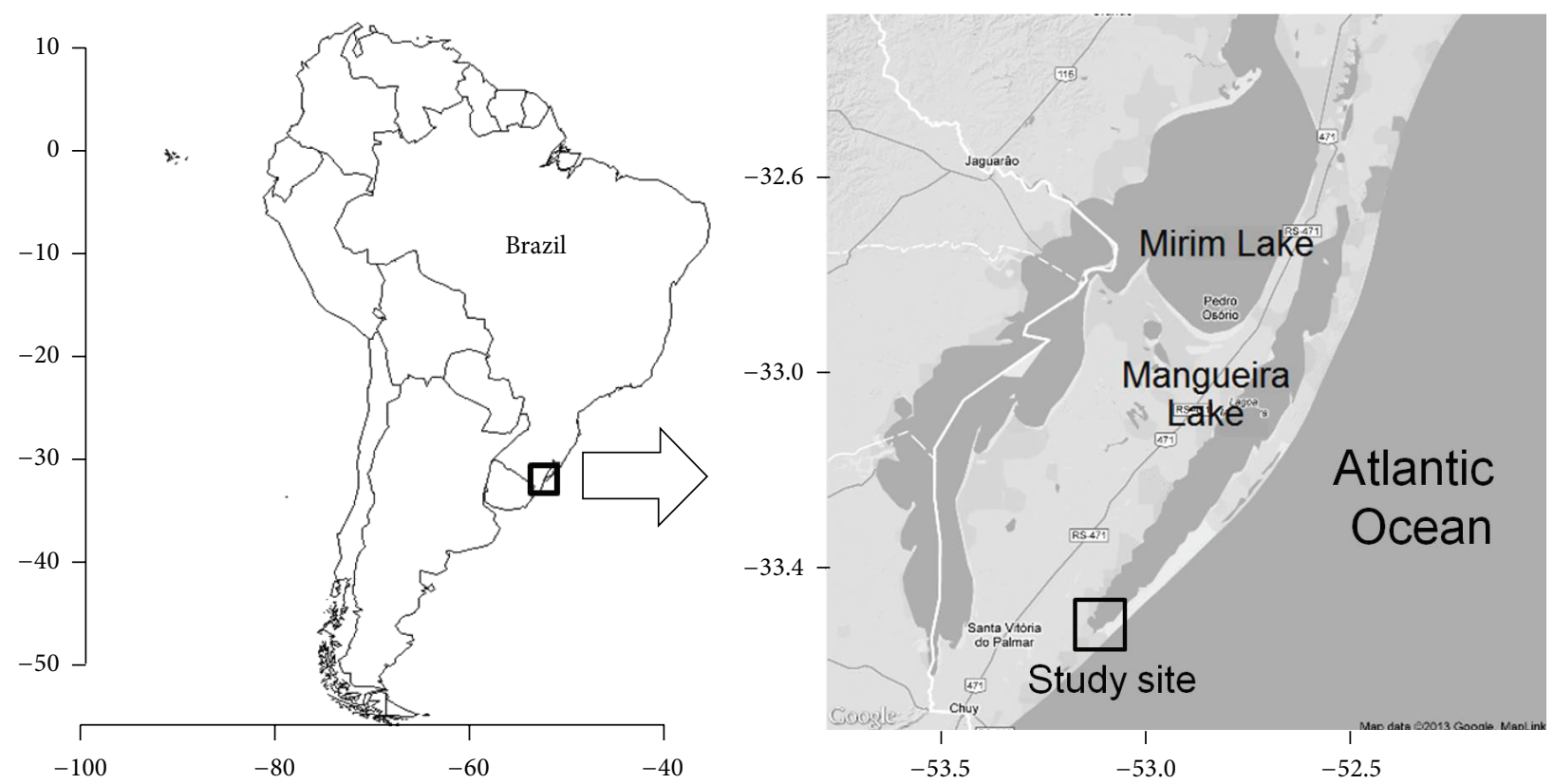

FIGURE 1: Sampling location: the large subtropical shallow Lake Mangueira in southern Brazil. The experiment was carried out in its southern part.

the bacterial fraction and addition of the inhibitor $\mathrm{HgCl}_{2}$ $\left(0.4 \mu \mathrm{gLL}^{-1}\right.$, final concentration), in order to isolate the photo-degradation effect. This inhibitor has no effect on photoreactivity (the capacity of undergoing oxidation by light) of DOM or UV-visible absorption spectra [25]. Polyethylene Whirl-Pak bags (Nasco, Pittsburgh, USA) of $500 \mathrm{~mL}$ capacity $(11.5 \times 23 \mathrm{~cm})$ were filled with $350 \mathrm{~mL}$ of each fraction. These bags are UV-transparent and did not present differences in bacterial activity in comparison with quartz containers during sunlight exposition [26]. Apart from the initial bags (9 bags), which were sampled just before the beginning of the incubation, 9 bags were protected from sunlight by doublewrapping with aluminum foil; the 9 remaining bags were exposed to natural sunlight. Because of the headspace in the bags, they floated at the surface and there was no water layer at the upper side of the bags; hence we assumed a negligible absorbance of UV by the water. The bags were randomly deployed on a plastic tray $\left(1 \mathrm{~m}^{2} \times 10 \mathrm{~cm}\right.$ high, open on the upper side) made of coarse-mesh shade cloth $(3 \mathrm{~cm} \times 1 \mathrm{~cm})$ tied to a floating PVC pipe square, also $1 \mathrm{~m}^{2}$. The tray was anchored in an unvegetated littoral zone at another point in the lake $(\approx 0.5 \mathrm{~m}$ depth), away from the sampling point, for $120 \mathrm{~h}$. Farjalla et al. [11] conducted an experiment with macrophyte leachates and bacterial decomposition and found an endpoint of $96 \mathrm{~h}$ of incubation when bacterial numbers reached a plateau, related to the total amount of available growth substrate. In our study, we extended this period by one day because of lack of prior knowledge of what endpoint would apply to our case.

2.4. Experimental Variables. The collection and preservation of samplings were carried according to Haig-They [17]. Samples for cell counting, biovolume, and biomass were fixed in $4 \%$ formaldehyde (vol: vol) in polyethylene bottles in the field and stored in the dark at $4^{\circ} \mathrm{C}$ until analysis. Samples of the bulk fraction were prefiltered on quantitative paper MN 640d Macherey-Nagel, mean mesh size 2.0 to $4.0 \mu \mathrm{m}$, in order to exclude organisms other than bacteria. In the laboratory, $2 \mathrm{~mL}$ of each sample was filtered $(<5.0 \mathrm{kPa})$ in a Vacuum Manifold Filtration Tower (Millipore, Billerica, MA) with $1 \mathrm{~mL}$ of Milli-Q water $(0.2 \mu \mathrm{m}$ filtered) to improve cell dispersion. Cells were concentrated on $0.2 \mu \mathrm{m}$ black polycarbonate membranes (GE). Approximately $1 \mathrm{~mL}$ of $10 \%$ (weight : vol) acridine orange stain was added to the filters for 5 min. They were then washed with Milli-Q water and airdried. Filters were mounted on slides with mineral oil (Nujol) and photographed within 3 days. A total of 10 images were captured per filter, and image processing was undertaken on six of them with the help of an image grab system. We employed a MOTIC 5000 cooled camera coupled to an Olympus IX70 inverted epifluorescence microscope (Center Valley, PA, USA). Image capture (MOTIC Image 3.2) and processing followed Massana et al. [27], with the help of the Freeware Image Tool (v.3.00). The processed and binarized images were then used for cell counts and determination of dimensions. Cell density was determined from the mean number of cells in 6 images and the cell-density equation of Kepner and Pratt [28]. Bacterial biovolume $\left(\mu \mathrm{m}^{-3}\right)$ was assigned to each cell according to the morphotype [27], utilizing the cell dimensions and morphotypes classification provided by CMEIAS/Image Tool (1.27) [29]. The mean biovolume per cell was calculated as the mean of all cells in all images. Bacterial biomass ( $\mathrm{pg} \mathrm{C} \mathrm{Cell}^{-1}$ ) was calculated employing an allometric function of biovolume [30], and the mean from all cells in all images was multiplied by the cell density to yield the bacterial carbon concentration of the 
sample (ng C mL ${ }^{-1}$ ). Bacterial production rates (BP) were estimated through the method of $\left(\mathrm{L}\left[4,5{ }^{3} \mathrm{H}\right]\right)$ radiolabeled leucine microcentrifugation. Incubations for bacterial production were carried out in Eppendorf vials $(2 \mathrm{~mL})$ and lasted 30 min inside a tray filled with lake water at room temperature $\left(15-16^{\circ} \mathrm{C}\right)$. Radioactivity counts were made after addition of $1 \mathrm{~mL}$ of scintillation liquid (Optiphase HiSafe III Wallac) in a Rack Beta Liquid Scintillation Counter (LKB Wallac 1209, Massachusetts, USA), for $180 \mathrm{~s}$ twice. The calculations assumed the isotopic dilution to be equal to 2 , the molar ratio of leucine in the protein pool to be 0.073 , and the ratio of carbon/protein contents to be $0.086[31,32]$.

The bacterial respiration in the fractions (bulk, bacterial, and control) was estimated as the rate of oxygen consumption, through the Winkler method [33], with colorimetric reading [34]. This method was conducted separately through a parallel incubation of the fractions in glass BOD bottles of $100 \mathrm{~mL}$ capacity. Incubation was done in the dark (doublewrapping the bottles with aluminum foil), with a total of 18 bottles ( 9 initial bottles and 9 final bottles, three triplicates of each of the three fractions), and then only comparisons among fractions could be made. The bottles were tied by their necks to another floating PVC pipe square that was anchored next to the incubating bags. For calculations, each final value of $\mathrm{O}_{2}$ was subtracted from the mean of the three initial bottles and divided by the incubation time, assuming constant respiration rate over time. The molar conversion factor between carbon and oxygen was assumed to be equal to 1.0 [35].

Bacterial Growth Efficiency (BGE) was computed according to equation (I) of del Giorgio et al. [36]: (I) BGE = $(\mathrm{BP}) /(\mathrm{BP}+\mathrm{BR})$, where $\mathrm{BP}$ is the bacterial production rate and $\mathrm{BR}$ is the bacterial respiration rate. Because respiration was recorded only for the three fractions, also BGE could only be calculated and compared among fractions. For the calculations, in order to match the results from respiration, we employed the mean of the bacterial production rate between the initial and final incubations.

Ciliates, Abs430, and Abs250:365 were measured the same way as for field samples $[8,21,24]$.

2.5. Statistical Treatment. Differences in the variables (bacterial density, biovolume, biomass, production, ciliate density, DOC, Abs $430 \mathrm{~nm}$, and Abs250:365 nm ratio) among initial, light and dark treatments in each fraction were tested with one-way ANOVA using R 2.13.1 [37]. Significant differences revealed by ANOVA were tested by Tukey's a posteriori test. Increases or decreases refer to the light and dark treatments in relation to the respective initial condition. Bacterial respiration and $\mathrm{BGE}$ were tested for differences among fractions and field condition through ANOVA and Tukey's test.

\section{Results}

The main limnological variables for the experimental conditions can be found in Table 1 . The global cumulative radiation (GR) during the experiment was $\approx 25455 \mathrm{KJ} \mathrm{m}^{-2}$. Total UV radiation received was estimated to be $\approx 58 \mathrm{~kJ} \mathrm{~m}^{-2}$.
Bacterial density did not differ among treatments in the bulk fraction; it increased with light exposure and decreased in the dark bags in the bacterial fraction. In the control fraction there was an increase in density in the dark treatment. Bacterial biovolume did not change with treatments. Bacterial biomass also showed no differences in the bulk fraction. It decreased in the dark treatment for the bacterial fraction and increased in the dark treatment in the control fraction (Table 2).

Bacterial production was unaltered in the bulk fraction. In the bacterial fraction, it decreased in the light treatment, and increased in the dark. In the control fraction it increased in the dark. Bacterial respiration and BGE did not differ among the fractions (Table 2).

Comparing the bacterial production with the field condition, only the dark control treatment showed a significant difference (ANOVA: $F(9,20)=29.41 ; P \ll 0.001$; dark control $>$ Field; $P \ll 0.001)$. Bacterial respiration did not differ from the field condition in any treatment (ANOVA: $F(3,8)=2.517$; $P=0.132)$. BGE decreased in the bulk and bacterial fraction incubations (ANOVA: $F(3,8)=4.92 ; P=0.0318$; Field $>$ Bulk: $P=0.058$; Field $>$ Bacterial: $P=0.052$ ).

In the bulk fraction, total ciliate density changed only in the light treatment. The light treatment, at its turn, decreased compared to the initial treatment. The dark incubation did not differ statistically from the initial treatment. The filtration procedure successfully excluded ciliates, as no ciliates were found in the bacterial and control fractions; any ciliate in the control was likely lysed by the toxic inhibitor (Table 2). No flagellates were found in the filtered samples under microscopic examination.

DOC and Abs250:365 showed no effect of treatment for any fraction. Abs430 (water color) was unaltered in the bulk fraction for all treatments; only the bacterial fraction showed significant color fading in the light treatment $(26 \%$ lower). The control light bags did not show any alteration with treatment, but the color was less intense than in the dark bags. Rates of fading in the light treatment were $0.0006,0.0014$, and 0.0012 day $^{-1}$ absorbance units for the bulk, bacterial, and control fractions, respectively (Table 2).

\section{Discussion}

The littoral zones of Lake Mangueira (especially in the north and south) are extensively colonized by emergent and submersed macrophytes, and these plants are expected to contribute large amounts of organic carbon to the system. Much of this carbon enters the lake in the form of DOM, which we found to show little reactivity (did not undergo decomposition by bacteria or light) during short-term incubation under in situ conditions. We were unable to detect changes in DOC, Abs250:365, and bacterial respiration, although the water color faded in the light bags. These results indicated that photodegradation did occur but did not modify carbon availability to bacteria. Exposure to light, however, had contrasting effects: it increased bacterial density in the bacterial fraction, suggesting a positive effect of light but decreased bacterial production in this same 
TABLE 1: Limnological and biological characterization of the water in the initial conditions of the experiment.

\begin{tabular}{cccccccccccccccc}
\hline$Z_{\text {mean }}$ & AT $^{1}$ & $\mathrm{pH}$ & $\mathrm{TS}$ & $\mathrm{Alk}$ & $\mathrm{TN}$ & $\mathrm{TP}$ & $\mathrm{DOC}$ & Abs430 & GR $^{2}$ & LMW & HMW & Abs250:365 & BP & BR & BGE \\
\hline \multirow{2}{*}{2.0} & 17.6 & 7.62 & 108 & 797 & 637 & 16.1 & 10.9 & 0.04 & 201.8 & 0.07 & 0.09 & 0.80 & 0.235 & 4.336 & 0.146 \\
& $(3.4)$ & $(0.07)$ & $(2.6)$ & $(72)$ & $(326)$ & $(2.6)$ & $(1.5)$ & $(0.001)$ & $(70)$ & $(0.006)$ & $(0.004)$ & $(0.060)$ & $(0.042)$ & $(4.255)$ & $(0.183)$ \\
\hline
\end{tabular}

${ }^{1}$ Mean air temperature for the 5 days of incubation.

${ }^{2}$ Mean daily flux of GR during incubation $(n=5) ; 1 \mathrm{~W}=1 \mathrm{~J} \mathrm{~s}^{-1}$. For all other variables, $n=3$.

${ }^{3}$ Figures in parentheses are \pm standard deviations.

${ }^{4} Z_{\text {mean }}$ : mean depth $(\mathrm{m})$; AT: air temperature $\left({ }^{\circ} \mathrm{C}\right)$; TS: total solids $\left(\mathrm{mg} \mathrm{L}^{-1}\right)$; Alk: alkalinity $\left(\mu \mathrm{Eq} \mathrm{L}{ }^{-1}\right)$; TN: total nitrogen $\left(\mu \mathrm{g} \mathrm{L}^{-1}\right)$; TP: total phosphorus $\left(\mu \mathrm{g} \mathrm{L}^{-1}\right)$; DOC: dissolved organic carbon $\left(\mathrm{mg} \mathrm{L}^{-1}\right)$; Abs430: absorbance at $430 \mathrm{~nm}$; GR: global radiation flux (W m ${ }^{-2}$ ); LMW: low-molecular-weight substances (absorbance at $250 \mathrm{~nm}$ ); HMW: high-molecular-weight substances (absorbance at $365 \mathrm{~nm}$ ); Abs250:365: (ratio of absorbances at 250 and $365 \mathrm{~nm}$ ); BP: bacterial production $\left(\mu \mathrm{g} \mathrm{C} \mathrm{L} \mathrm{h}^{-1}\right)$; BR: bacterial respiration $\left(\mu \mathrm{g} \mathrm{C} \mathrm{L} \mathrm{h}{ }^{-1}\right)$; BGE: bacterial growth efficiency.

treatment/fraction, suggesting photoinhibition. We did not examine the effect of exposure to light on respiration, but our results showed no difference in respiration from a previous measurement in the field (Table 1). The decrease in BGE with incubation can be attributed to the increase in respiration (even though there was no significant differences in respiration among fractions, it impacted the BGE calculation because respiration tended to be higher in bacterial and control fractions).

The general lack of changes in practically all variables in the bulk fraction indicates that there may be an interaction of grazing with radiation. The increase of bacterial density with light found in the bacterial fraction may have been impeded by grazing in the bulk fraction. Higher densities of bacteria and bacterial grazers have been found in UVirradiated DOC, suggesting that photo-degradation acts as a stimulus to microbial food webs [38]. In our case, however, the decrease in ciliate density with light treatment in the bulk fraction indicated a net effect of photoinhibition on ciliates. If they did control bacterial density, it was at a cost of a higher grazing rate per cell. On the other side, it has been found that high concentrations of refractory DOC like in humic lakes may be associated to lower bacterial, nanoflagellates and ciliates numbers and biomass and hence a less efficient functioning of the microbial loop, that is, lower rates of DOC reincorporation to the food web [39]. The density of ciliates in the initial condition (presumably a field concentration estimate) and inside the bags was low (24 orders of magnitude) when compared to values reported for lakes with variable trophic status, where they range from 1.9 to $100 \times 10^{6}$ cells m$^{-3}$ (see compilation in Gates [40]). This suggests that there may be a minor role of ciliates on the decomposition rates of this refractory DOC in Mangueira lake's littoral zones.

Unexpectedly, we found enhancement in bacterial density, biomass, and production in the dark treatment of the control fraction. This enhancement was first attributed to some kind of contamination, but since no ciliates were found in these bags and contamination in the three bags simultaneously is unlikely, this result was not disregarded. Although we were not able to explain this unexpected result, development of organisms capable of metabolizing mercury is possible. Several common bacterial genera (Escherichia, Enterobacter, and Bacillus) are able to resist $\mathrm{HgCl}_{2}$ through mercury methylation [41]. This has compromised the evaluation of the photo-degradation alone and needs to be critically considered.

An important point of our study is that we were able to find significant fading of DOM only in the light treatment of the bacterial fraction, which suggests the existence of a complementary pathway of dissolved organic degradation by bacteria and light [13]. Farjalla et al. [11] also found fading (in terms of 250, 365, and $430 \mathrm{~nm}$ absorbance) of DOM, but decreased bacterial density and production of bacteria in UVexposed macrophyte leachates, indicating that fading itself says little about the bioavailability of compounds formed. The increase in bacterial density, together with the stability of the DOC and Abs250:365, suggests that the photodegradation of high-molecular-weight compounds may have produced assimilable substances for bacterial growth $[9,10]$, but they were readily consumed by bacteria. Another important question still concerning mercury inside control bags is that this metal shows great affinity with organic matter, altering the conformation of the latter [42]; other bivalent heavy metals like $\mathrm{Cu}^{+2}, \mathrm{~Pb}^{+2}$, and $\mathrm{Cd}^{+2}$ have been found to change photochemistry of yellow substances and humic acids [43], and it is possible that mercury has had some unevaluated negative effect on photochemical reactivity in the bags where it was added to.

Simultaneous irradiation and incubation in our study may have exposed bacteria to continuous production of inhibitory free radicals, as suggested by the decrease in bacterial production. Many studies that dealt with bacterial utilization of photochemically transformed organic carbon derived from macrophytes employed an approach of pretreating the leachates with UV light prior to the incubation of bacterial batches [11, 13, 44]. In many cases, this prior exposure has been found to inhibit bacterial production and decrease growth efficiency, at least for a short period, which has been attributed to the formation of hydrogen peroxide and possibly other free radicals by light $[11,45]$. Formation of nonassimilable compounds is also possible. Seitzinger et al. [46] studied bacterial utilization of dissolved organic matter in two streams and found that BP increased greatly during two days of incubation, while DOC concentration significantly decreased (45-50\%) in 12 days. However, $60 \%$ of the compounds found in the complex mixture of organic molecules were not consumed, which Seitzinger et al. [46] 


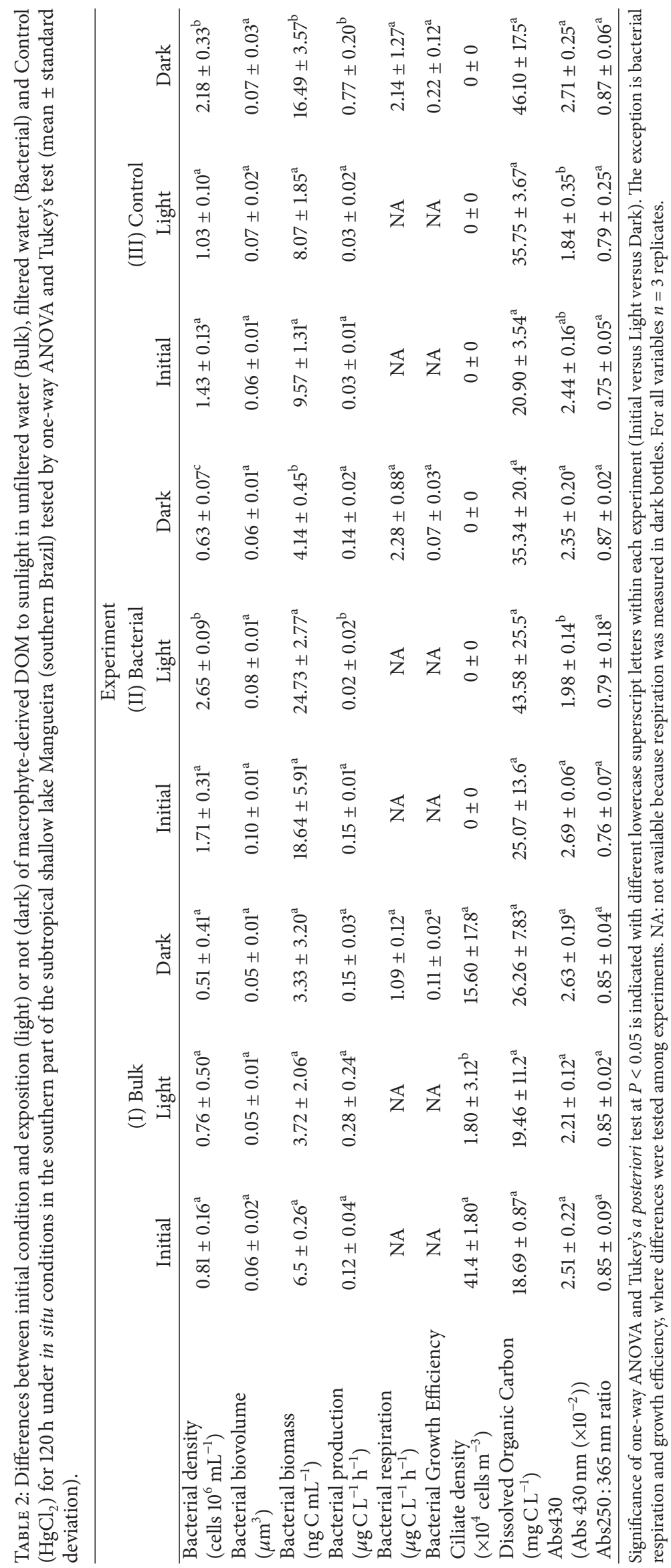


suggested may have resulted from some inhibition factor involved in their utilization. Contrastingly, Pérez et al. [12] exposed natural river-water DOM to light, also in a simultaneous exposure, and found bacterial enhancement with UV exposure. These differences could be due to variations in origin, age, and biochemical composition of the DOM [45].

The generally low bioavailability of DOC in the form of humic substances [6] indicates that a large proportion of the dissolved carbon in Lake Mangueira is refractory to bacterial consumption. This Abs250:365 ratio is higher in the littoral zone than in the pelagic zone, suggesting higher proportion of low-molecular-weight (LMW, Abs $250 \mathrm{~nm}$ ) substances in the littoral zone when compared to the pelagic zone. In fact, this was confirmed (pelagic Abs250: mean $=0.03$; standard deviation $=0.002 ; \mathrm{F}(1,4)=116.3, P<$ 0.001; littoral zone data obtained from Table 1). In spite of the smaller size of their molecules, these substances can be less reactive. Amon and Benner [4] conducted a crossenvironment experiment where they analyzed the reactivity of low-(LMW, <1 KDa) and high-molecular-weight (HMW, $>1 \mathrm{KDa}$ ) dissolved compounds and found significant changes in BP and BR during the experiment (also five days). Unexpectedly, these bacterial variables were higher in HMW substrates and, based on these results, the authors proposed the size-reactivity continuum model that predicts that the major path of degradation goes from large, highly reactive to small, highly recalcitrant molecules. If this hypothesis is broadly applicable to many ecosystems, it suggests that in Lake Mangueira the compounds lixiviated by the macrophyte belt had already degraded to some extent and accumulated as dissolved, unreactive LMW compounds with very low degradation rates in the littoral zones.

The age of the DOM subjected to bacterial degradation can be fundamental for its availability. In our experiment, we focused on the subsequent stage of macrophyte degradation, that is, after bacterial and light reworking had already occurred inside the macrophyte stands. Most studies that investigated microbial degradation of macrophytes focused on the early stages of degradation, with exposure of coarse fragments of macrophytes to leaching. For example, Wehr et al. [47] found a 4.5-fold increase in bacterial production after $168 \mathrm{~h}$ of incubation of macrophyte detritus. Conversely, Holm-Hansen et al. [48] demonstrated very low rates of microbial degradation of the emergent macrophyte Juncus effusus; only $23 \%$ of the total biomass in leaf litter bags was lost after 268 days. Enhancement of bacterial production might be related to the early stage of degradation, given that Kuehn et al. [49] employed senescent leaves in their experiment, a situation more similar to ours.

One possible explanation for the low photodegradation rates may be the total amount of UV accumulated during the experiment. In the study of Farjalla et al. [11], macrophyte leachates were photochemically transformed with total UV energy $\approx 5670 \mathrm{KJ} \mathrm{m}^{-2}$, which was able to induce a bacterial positive response. This UV intensity is almost 100 times higher than that estimated for the field conditions in the present study $\left(\approx 58 \mathrm{KJ} \mathrm{m}^{-2}\right)$. One implication is that, under laboratory conditions, the rates of photo-degradation may be overestimated compared to natural conditions. Another important point, however, is that polyethylene bags used in this study may present a reduced rate of UV transmittance (e.g., $68 \%$ of UVB at $300 \mathrm{~nm}$ ) [48]. Even though the transmittance increases slightly towards larger wavelengths [26], this quenching may have imposed slightly reduced rates of photo-degradation than in the field.

We attempted to determine the importance of the two main routes of carbon degradation in aquatic systems, that is, bacterial and photo-degradation, on macrophytederived DOM flowing into Lake Mangueira from a large wetland belt. Remarkably, our results showed few changes in environmental parameters related to carbon degradation (DOC, Abs250:365, and respiration), even though bacterial variables did show changes under light/dark incubation conditions $(120 \mathrm{~h})$. This DOM that enters the lake seems to be highly unreactive in a short-term and may be the cause for the difference in bacterial metabolism between the littoral and pelagic zones reported by $\mathrm{Ng}$ et al. [17], since this is the main carbon source for bacteria in the littoral zone. It is important to take into consideration that it was the first approach to the subject in this lake and was a onetime experiment; hence, more experimental replication is needed. Also there is a need for testing bacterial growth in dilution cultures, nutrients amendment, effects of light on respiration, and the size and quality spectra of DOM derived from macrophytes and phytoplankton to better address this subject. Another more speculative hypothesis is a possible allelopathic effect of macrophytes (mainly submersed), since this effect on cyanobacteria is largely known [50,51]. This has been considered as a possible explanation for lower bacterial diversity [52] and metabolism [17] in lake zones extensively colonized by macrophytes. Direct effects on heterotrophic bacteria, however, still need to be properly addressed.

\section{Conclusions}

In this study, we reported a short-term unchange in macrophyte-derived DOC availability with exposition to sunlight. This suggests that bacterial and photo-degradation can be very low under "in situ" conditions, which presents lower light intensity when compared to laboratory experiments, but more evidence is needed to determine if this is a permanent condition of the system. This study adds an important mechanistic explanation (low reactivity) for the previous finding that bacterial respiration is lower in littoral when compared to pelagic zones in lake Mangueira [53]. We hypothesize that, given the climatic conditions, continuous growth of macrophytes and loading of dissolved recalcitrant compounds contribute to very slow rates of DOC degradation and, in a short term, slight influence of photo-degradation. Submersed and emergent macrophytes cover extensive areas inside and around the drainage channel where we obtained the water for the present experiment, and similar extensive macrophyte coverage is common in many lakes across the world. The acknowledgment and further investigation on this subject are essential for the understanding of carbon cycling and metabolism in systems that are densely covered by macrophytes. 


\section{Conflict of Interests}

The authors state no conflict of interests involving any step of this study.

\section{Acknowledgments}

The authors draw particular attention to the assistance provided by the Chico Mendes Institute of Biodiversity (ICMBioESEC TAIM). Also they sincerely thank Dr. Laura Utz for helping with ciliate sampling and handling and Dr. Luiz Kucharski for providing the scintillation counter. They thank the Conselho Nacional de Desenvolvimento Científico e Tecnológico of Brazil (CNPq-Long Term Ecological Research Program, Site 7, Sistema Hidrológico do Taim) for financial support. They are also grateful to Dr. Janet W. Reid (JWR Associates) for revising the English text.

\section{References}

[1] R. G. Wetzel, "Gradient-dominated ecosystems: sources and regulatory functions of dissolved organic matter in freshwater ecosystems," Hydrobiologia, vol. 229, no. 1, pp. 181-198, 1992.

[2] G. H. Lauster, P. C. Hanson, and T. K. Kratz, "Gross primary production and respiration differences among littoral and pelagic habitats in northern Wisconsin lakes," Canadian Journal of Fisheries and Aquatic Sciences, vol. 63, no. 5, pp. 1130-1141, 2006.

[3] K. M. Docherty, K. C. Young, P. A. Maurice, and S. D. Bridgham, "Dissolved organic matter concentration and quality influences upon structure and function of freshwater microbial communities," Microbial Ecology, vol. 52, no. 3, pp. 378-388, 2006.

[4] R. M. W. Amon and R. Benner, "Bacterial utilization of different size classes of dissolved organic matter," Limnology and Oceanography, vol. 41, no. 1, pp. 41-51, 1996.

[5] L. Bracchini, A. Cózar, A. M. Dattilo et al., “The role of wetlands in the chromophoric dissolved organic matter release and its relation to aquatic ecosystems optical properties. A case of study: katonga and Bunjako Bays (Victoria Lake; Uganda)," Chemosphere, vol. 63, no. 7, pp. 1170-1178, 2006.

[6] U. Münster and R. J. Chróst, "Origin, composition, and microbial utilization of dissolved organic matter," in Aquatic Microbial Ecology, J. Overbeck and R. J. Chróst, Eds., pp. 8-46, Springer, New York, NY, USA, 1990.

[7] D. O. Hessen, "Dissolved organic carbon in a humic lake: effects on bacterial production and respiration," Hydrobiologia, vol. 229, no. 1, pp. 115-123, 1992.

[8] M. J. Lindell, W. Granéli, and L. J. Tranvik, "Enhanced bacterial growth in response to photochemical transformation of dissolved organic matter," Limnology and Oceanography, vol. 40, no. 1, pp. 195-199, 1995.

[9] M. A. Moran and R. G. Zepp, "Role of photoreactions in the formation of biologically labile compounds from dissolved organic matter," Limnology and Oceanography, vol. 42, no. 6, pp. 1307-1316, 1997.

[10] S. Bertilsson and L. J. Tranvik, "Photochemically produced carboxylic acids as substrates for freshwater bacterioplankton," Limnology and Oceanography, vol. 43, no. 5, pp. 885-895, 1998.
[11] V. F. Farjalla, A. M. Anesio, S. Bertilsson, and W. Granéli, "Photochemical reactivity of aquatic macrophyte leachates: abiotic transformations and bacterial response," Aquatic Microbial Ecology, vol. 24, no. 2, pp. 187-195, 2001.

[12] A. P. Pérez, M. M. Diaz, M. A. Ferraro, G. C. Cusminsky, and H. E. Zagarese, "Replicated mesocosm study on the role of natural ultraviolet radiation in high CDOM, shallow lakes," Photochemical and Photobiological Sciences, vol. 2, no. 2, pp. 118123, 2003.

[13] A. M. Amado, V. F. Farjalla, F. D. A. Esteves, R. L. Bozelli, F. Roland, and A. Enrich-Prast, "Complementary pathways of dissolved organic carbon removal pathways in clear-water Amazonian ecosystems: photochemical degradation and bacterial uptake," FEMS Microbiology Ecology, vol. 56, no. 1, pp. 8-17, 2006.

[14] S. G. Ribblett, M. A. Palmer, and D. W. Coats, "The importance of bacterivorous protists in the decomposition of stream leaf litter," Freshwater Biology, vol. 50, no. 3, pp. 516-526, 2005.

[15] R. A. Snyder and M. P. Hoch, "Consequences of protiststimulated bacterial production for estimating protist growth efficiencies," Hydrobiologia, vol. 341, no. 2, pp. 113-123, 1996.

[16] N. Rooney and J. Kalff, "Interactions among epilimnetic phosphorus, phytoplankton biomass and bacterioplankton metabolism in lakes of varying submerged macrophyte cover," Hydrobiologia, vol. 501, pp. 75-81, 2003.

[17] H.-T. Ng, D. da Motta Marques, E. Jeppesen, and M. Søndergaard, "Bacterioplankton in the littoral and pelagic zones of subtropical shallow lakes," Hydrobiologia, vol. 646, no. 1, pp. 311-326, 2010.

[18] L. O. Crossetti, L. S. Cardoso, V. L. M. Callegaro et al., "Influence of the hydrological changes on the phytoplankton structure and dynamics in a subtropical wetland-lake system," Acta Limnologica Brasiliensia, vol. 19, pp. 315-329, 2007.

[19] C. R. Fragoso Jr., D. M. L. M. Marques, W. Collischonn, C. E. M. Tucci, and E. H. van Nes, "Modelling spatial heterogeneity of phytoplankton in Lake Mangueira, a large shallow subtropical lake in South Brazil," Ecological Modelling, vol. 219, no. 1-2, pp. 125-137, 2008.

[20] J. C. Ceballos and M. L. Rodrigues, "Estimativa de insolação mediante satélite geoestacionário: resultados preliminares," in Proceedings of 15th Congresso Brasileiro de Meteorologia, INPE, São Paulo, Brazil, 2008.

[21] R. G. Wetzel and G. E. Likens, Limnological Analyses, Springer, New York, NY, USA, 3rd edition, 2000.

[22] American Public Health Association, American Water Works Association, and Water Environment Federation, Standard Methods For the Examination of Water and Wastewater, American Public Health Associatio, Washington, DC, USA, 20th edition, 1999.

[23] F. J. H. Mackereth, J. Heron, and J. F. Talling, Water Analysis: Some Revised Methods For Limnologists, Freshwater Biological Association, Ambleside, UK, 2nd edition, 1989.

[24] D. J. Strome and M. C. Miller, "Photolytic changes in dissolved humic substances," Verhandlungen der Internationalen Vereinigung für Theoretische und Angewandte Limnologie, vol. 20, pp. 1248-1254, 1978.

[25] J. R. Helms, A. Stubbins, J. D. Ritchie, E. C. Minor, D. J. Kieber, and K. Mopper, "Absorption spectral slopes and slope ratios as indicators of molecular weight, source, and photobleaching of chromophoric dissolved organic matter," Limnology and Oceanography, vol. 53, no. 3, pp. 955-969, 2008. 
[26] P. Aas, M. M. Lyons, R. Pledger, D. L. Mitchell, and W. H. Jeffrey, "Inhibition of bacterial activities by solar radiation in nearshore waters and the Gulf of Mexico," Aquatic Microbial Ecology, vol. 11, no. 3, pp. 229-238, 1996.

[27] R. Massana, J. M. Gasol, P. K. Bjørnsen et al., "Measurement of bacterial size via image analysis of epifluorescence preparations: description of an inexpensive system and solutions to some of the most common problems," Scientia Marina, vol. 61, no. 3, pp. 397-407, 1997.

[28] R. L. J. R. Kepner Jr. and J. R. Pratt, "Use of fluorochromes for direct enumeration of total bacteria in environmental samples: past and present," Microbiological Reviews, vol. 58, no. 4, pp. 603-615, 1994.

[29] J. Liu, F. B. Dazzo, O. Glagoleva, B. Yu, and A. K. Jain, “CMEIAS: a computer-aided system for the image analysis of bacterial morphotypes in microbial communities," Microbial Ecology, vol. 41, no. 3, pp. 173-194, 2001.

[30] S. Norland, "The relationship between biomass and volume of bacteria," in Handbook of Methods in Aquatic Microbial Ecology, P. F. Kemp, B. F. Sherr, E. B. Sherr, and J. J. Cole, Eds., pp. 339345, Lewis, Chelsea, Mich, USA, 1993.

[31] D. C. Simon and F. Azam, "A simple, economical method for measuring bacterial protein synthesis rates in sea water using ${ }^{3}$ H-leucine," Marine Microbial Food Webs, vol. 6, pp. 107-109, 1992.

[32] D. Kirchman, "Measuring bacterial biomass production and growth rates from leucine incorporation in natural aquatic environments," in MarIne Microbiology-Methods In Microbiology, J. H. Paul, Ed., pp. 227-237, Academic Press, San Diego, Calif, USA, 30th edition, 2001.

[33] H. L. Golterman, R. S. Clymo, and M. A. M. Ohnstad, Methods for Physical and Chemical Analysis of Fresh Waters, Blackwell Publishing Company, London, UK, 2nd edition, 1978.

[34] P. Del Giorgio, "Rapid and precise determination of dissolved oxygen by spectrophotometry: evaluation of interference from color and turbidity," Limnology and Oceanography, vol. 44, no. 4, pp. 1148-1154, 1999.

[35] P. A. del Giorgio, J. J. Cole, and A. Cimbleris, "Respiration rates in bacteria exceed phytoplankton production in unproductive aquatic systems," Nature, vol. 385, no. 6612, pp. 148-151, 1997.

[36] P. A. del Giorgio and J. J. Cole, "Bacterial growth efficiency in natural aquatic systems," Annual Review of Ecology and Systematics, vol. 29, pp. 503-541, 1998.

[37] R Development Core Team, R: A Language and Environment For Statistical Computing, R Foundation for Statistical Computing, Vienna, Austria, 2011, http://www.R-project.org/.

[38] H. J. de Lange, D. P. Morris, and C. E. Williamson, "Solar ultraviolet photodegradation of DOC may stimulate freshwater food webs," Journal of Plankton Research, vol. 25, no. 1, pp. 111117, 2003.

[39] K. Kalinowska, "Bacteria, nanoflagellates and ciliates as components of the microbial loop in three lakes of different trophic status," Polish Journal of Ecology, vol. 52, no. 1, pp. 19-34, 2004.

[40] M. A. Gates, "Quantitative importance of ciliates in the planktonic biomass of lake ecosystems," Hydrobiologia, vol. 108, no. 3 , pp. 233-238, 1984.

[41] M. K. Hamdy and O. R. Noyes, "Formation of methyl mercury by bacteria," Journal of Applied Microbiology, vol. 30, no. 3, pp. 424-432, 1975.

[42] M. Ravichandran, "Interactions between mercury and dissolved organic matter-a review," Chemosphere, vol. 55, no. 3, pp. 319331, 2004
[43] G. M. Ferrari, "Influence of $\mathrm{pH}$ and heavy metals in the determination of yellow substance in estuarine areas," Remote Sensing of Environment, vol. 37, no. 2, pp. 89-100, 1991.

[44] A. M. Anesio, J. Theil-Nielsen, and W. Granéli, "Bacterial growth on photochemically transformed leachates from aquatic and terrestrial primary producers," Microbial Ecology, vol. 40, no. 3, pp. 200-208, 2000.

[45] A. M. Anesio, W. Granéli, G. R. Aiken, D. J. Kieber, and K. Mopper, "Effect of humic substance photodegradation on bacterial growth and respiration in lake water," Applied and Environmental Microbiology, vol. 71, no. 10, pp. 6267-6275, 2005.

[46] S. P. Seitzinger, H. Hartnett, R. Lauck et al., "Molecularlevel chemical characterization and bioavailability of dissolved organic matter in stream water using electrospray-ionization mass spectrometry," Limnology and Oceanography, vol. 50, no. 1, pp. 1-12, 2005.

[47] J. D. Wehr, J. Petersen, and S. Findlay, "Influence of three contrasting detrital carbon sources on planktonic bacterial metabolism in a mesotrophic lake," Microbial Ecology, vol. 37, no. 1, pp. 23-35, 1999.

[48] O. Holm-Hansen, E. W. Helbling, B. B. Prézelin, and R. C. Smith, "Polyethylene bags and solar ultraviolet radiation," Science, vol. 259, no. 5094, pp. 534-535, 1993.

[49] K. A. Kuehn, M. J. Lemke, K. Suberkropp, and R. G. Wetzel, "Microbial biomass and production associated with decaying leaf litter of the emergent macrophyte Juncus effusus," Limnology and Oceanography, vol. 45, no. 4, pp. 862-870, 2000.

[50] E. M. Gross, S. Hilt, P. Lombardo, and G. Mulderij, "Searching for allelopathic effects of submerged macrophytes on phytoplankton-state of the art and open questions," Hydrobiologia, vol. 584, no. 1, pp. 77-88, 2007.

[51] G. Mulderij, E. H. van Nes, and E. van Donk, "Macrophytephytoplankton interactions: the relative importance of allelopathy versus other factors," Ecological Modelling, vol. 204, no. 1-2, pp. 85-92, 2007.

[52] Q. L. Wu, G. Zwart, J. Wu, M. P. Kamst-van Agterveld, S. Liu, and M. W. Hahn, "Submersed macrophytes play a key role in structuring bacterioplankton community composition in the large, shallow, subtropical Taihu Lake, China," Environmental Microbiology, vol. 9, no. 11, pp. 2765-2774, 2007.

[53] N. H. They, D. M. Marques, and R. S. Souza, "Lower respiration in the littoral zone of a subtropical shallow lake," Frontiers in Microbiology, vol. 3, p. 434, 2012. 

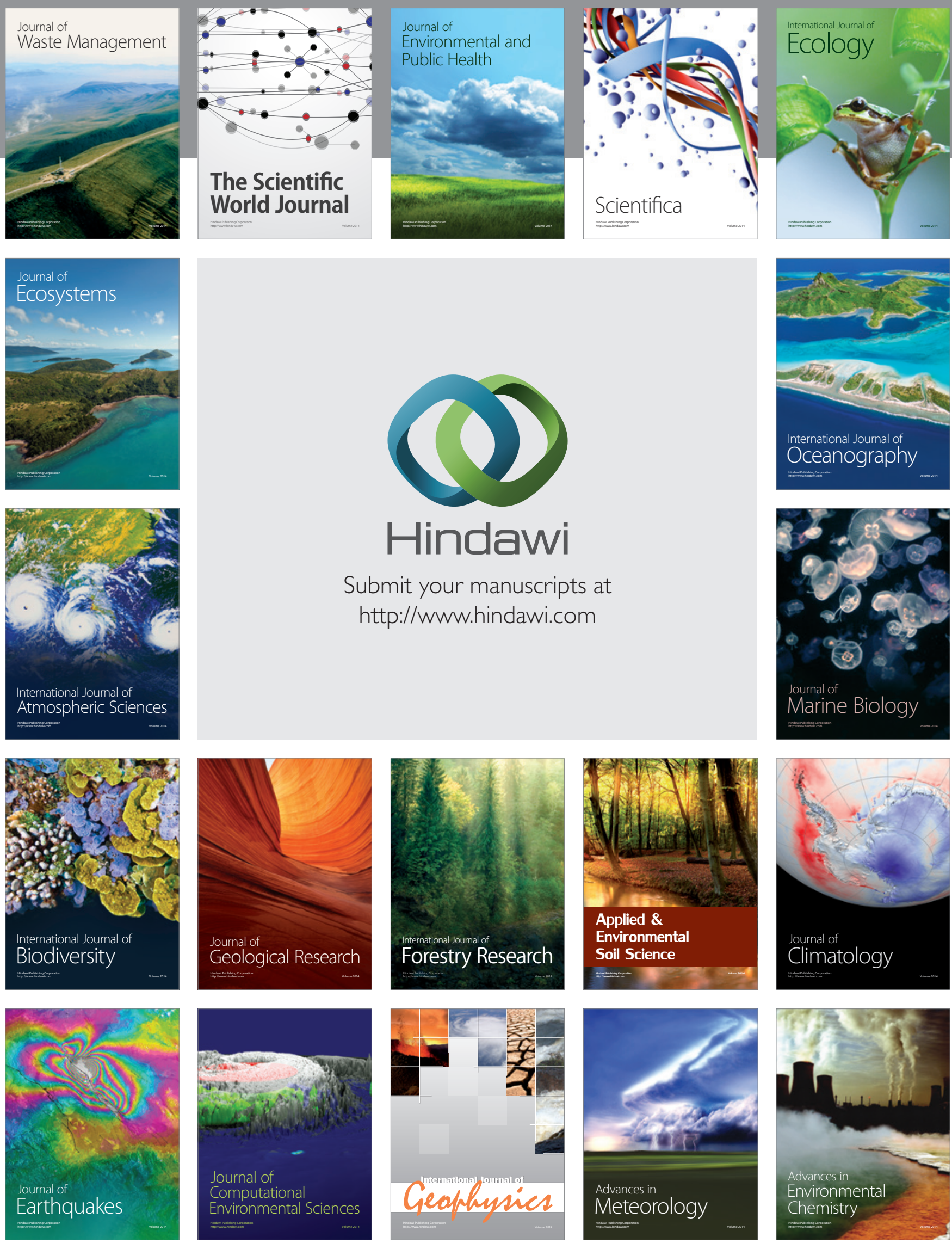